\title{
Awareness of Parents about Montessori Education: A Sample of Ankara \& Seattle ${ }^{1}$
}

\author{
Sevinc Ucar ${ }^{2}$ \\ Ender Durualp ${ }^{3}$
}

\begin{abstract}
Abstact
The purpose of this study is to examine the Montessori awareness of parents living in Ankara and living in Seattle and whose children are attending Montessori preschool. The study group of the research was created by 61 parents whose children are attending Montessori Preschool in Turkey/Ankara and 21 parents whose children are attending Montessori Preschool in USA/Seattle. The research data were collected through "General Information Form" and "Parent Conception Form". While General Information Form has demographic questions, Parent Conception Form has questions about Montessori education to gauge awareness of parents. Parent Conception Form is a three point Likert-type form. Statistical Package for the Social Sciences (SPSS) was used in the analysis of the data. Frequency and percentage values are used in the analysis of the data. As a result of the research, it was determined that the parents living in Ankara and sending their children Montessori Preschool in Ankara have similar thoughts to parents living in Seattle and sending their children Montessori Preschool in Seattle. It has been determined that all parents that is included in the research have knowledge about the Montessori approach-based education.
\end{abstract}

Key words: Montessori approach, parents, preschool education, early years, early childhood education.

\section{Introduction}

The period in which the child is proceed with the physical, motor, language, cognitive and social-emotional development and self-care skills and when the child's personality structure begins to shape is the period of early childhood that covers the first years of life. The features that are earned in early childhood will affect all life. Putting this period to good use, supporting the development and educa tion of the child is very important for the growth of healthy individuals. In this context, the educational environment and opportunities offered to the child contribute to the development of the child. Studies show that the development of children who spent their early childhood years efficiently is better than who haven't. (Durualp \& Aral, 2010)

Early childhood period is very important period in which the bases of all life skills of the individual are laid. It has been scientifically proven that learning habits, knowledge and

\footnotetext{
${ }^{1}$ This study is an extended version of a presentation held at the first International EDUREF Symposium, which was April 6-7, 2018 in Ankara, Turkey.

2 Ankara University Institute of Health Sciences Department of Child Development, ucar.sevinc[at]gmail.com

3 Assoc. Prof. Dr., Ankara University, Faculty of Health Sciences Department of Child Development endora2212 [at]hotmail.com
} 
skills that children earned in the first years of life are transferred into the later years of life. In this context, it is necessary for children to be supported and guided facultative and properly in the early childhood years (MEB, 2006). Discovery of the child's potentials, meeting the needs of the child, building basic habits, to prepare the child to the life in the best way possible can be accomplished with qualified preschool education (Oktay \& Polat Unutkan, 2005).

Different educational approaches and models have a role in effectively passed early childhood years. Educational approaches presented in these years can gain children positive features and different perspectives. The Montessori Approach is one of the early childhood programs and it provides positive contributions to many areas of child's development (Aral et al., 2015).

It has been found that Montessori based approach education provides positive contributions to the development of children's creativity (Can Yaşar \& Aral, 2010), the development of dexterity (Beken \& Şen, 2009), reading and writing exercises (Durakoğlu, 2010), freedom of the child (Güral, 2015), creative thinking (Şahintürk, 2012) .

The Montessori approach offers an educational environment that allows children to use their own potential with the help of specially trained Montessori teachers and specially developed Montessori materials (Mallor, 1989). Montessori education is developed to make children curious for learning, let them learn what they really interested in (Lillard, 1972).

There is prepared environment for children in Montessori schools. Everything in the Montessori schools is child size so that children can use and carry materials by themselves. For instance; table, chair, hooks for their coats, aprons, brooms... (Hainstock, 1997).

In Montessori classrooms, the environment does not include pictures, tables, as in a traditional preschool classroom decoration. Children are not offered unlimited activities. Conversely they choose an activity from within limited activity options, which is the basic feature of Montessori classes. The "prepared environment" in Montessori classes reflects that teacher's focus point is the interest of the child and sensorial training of the child (Montessori, 1965).

Maria Montessori says that teachers are part of the prepared environment and thereby the first thing teachers should do is to prepare themselves well (Montessori, 1965) (Montessori, 1995). According to Maria Montessori, the teacher should be a representative of the learning environment. Creating an attractive environment and to observe and protect this environment should also be the tasks of the teacher. Maria Montessori also considers the teacher's appearance as the first step in winning children's trust and respect (Montessori, 1995).

The main purpose of Maria Montessori's definition of teachers as "guides" is that teachers are not in the teaching role and they help children to develop their own capacities in Montessori schools (Lillard, 1972).

In the Montessori class, children are self-motivated when they are going to do an activity or work with a material. The role of the teacher is not to motivate the children, but to support their development and independence (Montessori, 1967). 
Montessori based education that is given in many countries in the world has started to become widespread in our country in recent years. Educational settings, curriculums, materials used, physical environment, rich stimuli and family are important parts of the education given in early childhood. Parents' knowledge, opinions, thoughts and awareness about Montessori education seems important for children and their families. Therefore it is aimed to examine the views and awareness of parents sending their children to Montessori based Preschool. In the research, awareness of parents living in Turkey/Ankara was compared with awareness of parents living in USA/Seattle.

\section{Research Method}

\section{The Purpose of the Research}

Montessori based education has started to popular in Turkey recently. The number of Montessori schools in Turkey is increasing day after day. Under the circumstances, the question "whether the parents really have knowledge about this educational approach" comes to mind. Therefore it is aimed to examine the views and awareness of parents sending their children to Montessori based Preschool. In the research, awareness of parents living in Turkey/Ankara was compared with awareness of parents living in USA/Seattle.

\section{Research Model}

The research reveals parents' awareness of Montessori education, who send their child to Montessori preschools. In this context, descriptive survey model was used to reveal parents' awareness of Montessori education.

\section{Study Group of the Research}

Parents living in Ankara and parents living in Seattle who has children 3 to 6 ages were included in the research. The study group of the research was created by 61 parents whose children are attending a Montessori Preschool in Turkey/Ankara and 21 parents whose children are attending a Montessori Preschool in US/Seattle.

\section{Data Collection Tools}

The research data were collected through "General Information Form" and "Parent Conception Form". While "General Information Form" has demographic questions, "Parent Conception Form" has questions about Montessori education to gauge awareness of parents. After the questionnaire was prepared, it was presented to two specialists (Proffessor Dr. Müdriye YILDIZ BIÇAKÇI and Professor Dr. Aysel KÖKSAL AKYOL at Ankara University, Faculty of Health Sciences, and Department of Child Development) in the field for their comments. The questionnaire was reconstructed taking into account the experts' opinions. Final version of the questionnaire was translated into English and then sent to a linguist for his comments. English version of the questionnaire was finalized taking into account of the expert's opinions.

\section{Data Collection Procedure}

The research data was collected between October and December 2016, after obtaining the necessary permits from Montessori Schools. The opinions of the parents living 
in Ankara were collected by hard-copy questionnaires in cooperation with the school administrator. The opinions of the parents living in Seattle were collected by sending the online questionnaires via the school's mail network in cooperation with the school administrator.

\section{Data Analysis}

IBM SPSS STATISTICS V23.0 was used in the analysis of the data. Frequency and percentage values are used in the analysis of the data. No comparative analysis was performed for the two groups. The results of both groups were examined independently from each other and the results were shown only in percent.

\section{Limitations to the Study}

The number of participants is low so the research cannot be generalized. Since time was limited for collecting data and data collecting process took place at the same time as the Christmas, the number of US participants is lower than TR participants.

\section{Results and Discussion}

The data collected in order to compare parents' views and awareness of Montessori education are presented in tabular and discussed in the related literature.

Table1. Socio-demographic characteristics of the parents

\begin{tabular}{|lcccc|}
\hline \multicolumn{1}{c}{ ANKARA } & \multicolumn{2}{c|}{ SEATTLE } \\
\hline Variables & n & \% & n & \% \\
\hline Gender & 29 & 47,5 & 1 & 4,8 \\
Male & 32 & 52,5 & 20 & 95,2 \\
Female & & & & \\
Age & 23 & 37,7 & 6 & 28,6 \\
$31-35$ & 24 & 39,3 & 5 & 23,8 \\
$36-40$ & 9 & 14,8 & 8 & 38,1 \\
$41-45$ & 5 & 8,2 & 2 & 9,5 \\
$46+$ & & & & \\
\hline Education & 1 & 1,6 & - & - \\
High School & 2 & 3,3 & 4 & 19,0 \\
Asscociated Degree & 23 & 37,7 & 8 & 38,1 \\
Bachelor Degree & 35 & 57,4 & 9 & 42,9 \\
Post-graduate & & & & \\
\hline Family Type & 59 & 96,7 & 18 & 85,7 \\
Nuclear Family & 2 & 3,3 & 3 & 14,3 \\
Extended Family & 35 & 57,4 & 7 & 33,3 \\
\hline Number of Family Members & & & & \\
1-3 & 26 & 42,6 & 14 & 66,7 \\
4-6 & 1 & 1,6 & 2 & 9,5 \\
\hline Level of Income & 13 & 21,3 & 6 & 28,6 \\
1300-3000 & 47 & 77,1 & 13 & 61,9 \\
3000-6000 & & &
\end{tabular}




\begin{tabular}{|lcccc|} 
Age of Wife/Husband & & & & \\
\hline $31-35$ & 24 & 39,3 & 3 & 14,3 \\
$36-40$ & 24 & 39,3 & 3 & 14,3 \\
$41-45$ & 10 & 16,5 & 9 & 42,9 \\
$46-50$ & 3 & 4,9 & 6 & 28,6 \\
Education of Wife/Husband & & & \\
\hline High School & 2 & 3,3 & 7 & 33,3 \\
Associated Degree & 1 & 1,6 & 1 & 4,8 \\
Bachelor Degree & 37 & 60,7 & 4 & 19,0 \\
Post-graduate & 21 & 34,4 & 9 & 42,9 \\
\hline
\end{tabular}

The socio-demographic characteristics of the parents in Seattle are as follows; $95.2 \%$ of participants are mother, $38,1 \%$ of participants are between the age of $41-45,42.9 \%$ of participants have post graduate degree, $85.7 \%$ of participants have nuclear family, $61.9 \%$ of participants have 4-6 family members living together , $61.9 \%$ of participants have $6000 \$$ and over income (monthly)

The socio-demographic characteristics of the parents in Ankara are as follows; $52.5 \%$ of participants are mother, $39.3 \%$ of participants are between the ages of $36-40,57.4 \%$ of participants have post graduate degree, $96.7 \%$ of participants have nuclear family, $57.4 \%$ of participants have 1-3 family members living together, and $77.1 \%$ of participants have $6000 \mathrm{TL}$ and over income (monthly).

Table 2 Features of Parents about Montessori Education

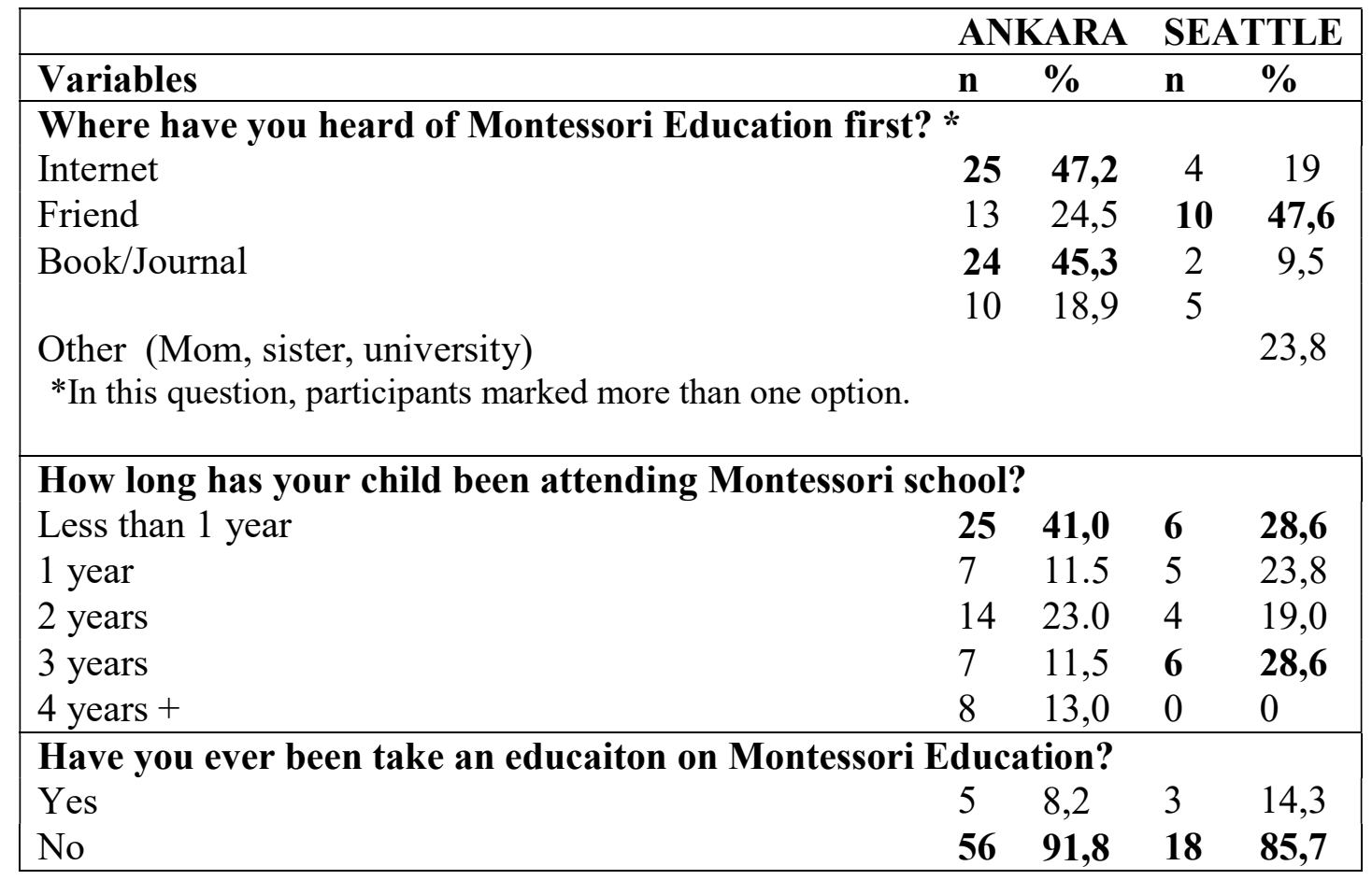

47.2\% of participants living in Ankara heard Montessori education for the first time from internet, $41.0 \%$ of participants' children have been attending Montessori school less than 1 year. $47.6 \%$ of participants living in Seattle heard Montessori education for the first time 
from their friend, $28.6 \%$ of participants' children have been attending Montessori school less than 1 year and three years.

91.8\% of the parents living in Ankara and $85.7 \%$ of the parents living in Seattle did not receive any education about Montessori. Parents living in Ankara stated that they had received an education from the ODTÜ Alumni Association and Montessori Kindergarten which they send their children $(8.2 \%)$. Parents living in Seattle stated that they were trained at the North American Montessori Center, Montessori Center for Teacher Education (MCTE), Rochester, Michigan and San Leandro, California USA (14.3\%). Being educated in Montessori creates awareness in parents. Thanks to the trainings, parents are able to learn Montessori education closely. Montessori-trained parents choose a preschool that offers Montessori education when they are looking for a preschool for their children. Therefore, these parents are able to express expectations from a pre-school better than other parents and they select a preschool for their children more consciously.

Parents were asked with the open-ended question in the form "What do you think the Montessori education will bring to your children?". $40.9 \%$ of parents living in Ankara answered this question self-confidence, $13.1 \%$ of parents self-sufficient, $9.8 \%$ independence, and $9.8 \%$ support social development. $23.8 \%$ of parents living in Seattle answered this question self-esteem, $23.8 \%$ independence, $23.8 \%$ natural love of learning, $9.5 \%$ explorative learning. From the responses given, it seems that there are similar expectations in both study groups.

Table 3 Parents Awareness of Montessori Education (Sample of Ankara)

\begin{tabular}{|l|c|c|c|c|c|c|}
\hline \multirow{2}{*}{ Statement* } & \multicolumn{2}{|c|}{ DISAGREE } & \multicolumn{2}{c|}{$\begin{array}{c}\text { SOMEWHAT } \\
\text { AGREE }\end{array}$} & \multicolumn{2}{c|}{$\begin{array}{c}\text { STRONGLY } \\
\text { AGREE }\end{array}$} \\
\cline { 2 - 7 } & $\mathbf{n}$ & $\%$ & $\mathbf{n}$ & $\mathbf{2}$ & $\mathbf{n}$ & $\mathbf{\%}$ \\
\hline $\begin{array}{l}\text { 1. Montessori education improves } \\
\text { concentration of children. }\end{array}$ & - & - & 25 & 41 & $\mathbf{3 6}$ & $\mathbf{5 9}$ \\
\hline $\begin{array}{l}\text { 2. Montessori classrooms have multiple sets of } \\
\text { classroom material for each activity so that } \\
\text { children do not have to wait for a turn. }\end{array}$ & $\mathbf{3 5}$ & $\mathbf{5 7 , 4}$ & 16 & 26,2 & 10 & 16,4 \\
\hline $\begin{array}{l}\text { 3. Montessori education supports children's } \\
\text { development of self-discipline. }\end{array}$ & - & - & 6 & 9,8 & $\mathbf{5 5}$ & $\mathbf{9 0 , 2}$ \\
\hline $\begin{array}{l}\text { 4. Montessori education supports } \\
\text { independency of children. }\end{array}$ & - & - & 5 & 8,2 & $\mathbf{5 6}$ & $\mathbf{9 1 , 8}$ \\
\hline $\begin{array}{l}\text { 5. Montessori education is only for children } \\
\text { who need special education. }\end{array}$ & $\mathbf{5 9}$ & $\mathbf{9 6 , 8}$ & 1 & 1,6 & 1 & 1,6 \\
\hline $\begin{array}{l}\text { 6. Montessori education focuses on academic } \\
\text { success. }\end{array}$ & $\mathbf{4 6}$ & $\mathbf{7 5 , 4}$ & 12 & 19,7 & 3 & 4,9 \\
\hline $\begin{array}{l}\text { 7. Montessori education is only suitable for } \\
\text { gifted children. }\end{array}$ & $\mathbf{5 9}$ & $\mathbf{9 6 , 7}$ & 2 & 3,3 & - & - \\
\hline
\end{tabular}




\begin{tabular}{|c|c|c|c|c|c|c|}
\hline $\begin{array}{l}\text { 8. Children in Montessori classrooms, work at } \\
\text { their own pace. }\end{array}$ & 2 & 3,3 & 17 & 27,9 & 42 & 68,8 \\
\hline $\begin{array}{l}\text { 9. Montessori education puts pressure on } \\
\text { children about academic success. }\end{array}$ & 59 & 96,7 & 2 & 3,3 & - & - \\
\hline $\begin{array}{l}\text { 10. Montessori education supports creative } \\
\text { thinking. }\end{array}$ & - & - & 10 & 16,4 & 51 & 83,6 \\
\hline $\begin{array}{l}\text { 11. Montessori education supports children } \\
\text { develop their reading and writing skills. }\end{array}$ & 3 & 4,9 & 21 & 34,4 & 37 & 60,7 \\
\hline $\begin{array}{l}\text { 12. Children choose a work through the } \\
\text { will of Montessori teacher. }\end{array}$ & 40 & 65,6 & 13 & 21,3 & 8 & 13,1 \\
\hline $\begin{array}{l}\text { 13. Montessori education supports } \\
\text { children's ability of math. }\end{array}$ & - & - & 19 & 31,1 & 42 & 68,9 \\
\hline $\begin{array}{l}\text { 14. Play is the work of the child according } \\
\text { to Montessori education. }\end{array}$ & 6 & 9,8 & 20 & 32,8 & 35 & 57,4 \\
\hline $\begin{array}{l}\text { 15. Children meet some biological terms } \\
\text { such as sea animals, farm animals and the } \\
\text { life cycle of animals. }\end{array}$ & 1 & 1,6 & 15 & 24,6 & 45 & 73,8 \\
\hline $\begin{array}{l}\text { 16. Montessori education supports social } \\
\text { skills of children. }\end{array}$ & - & - & 7 & 11,5 & 54 & 88,5 \\
\hline $\begin{array}{l}\text { 17. Children in Montessori classrooms } \\
\text { decide on what they want to work/learn by } \\
\text { themselves. }\end{array}$ & 1 & 1,6 & 17 & 27,9 & 43 & 70,5 \\
\hline $\begin{array}{l}\text { 18. Montessori classrooms have a prepared } \\
\text { environment with materials specially } \\
\text { designed for Montessori education. }\end{array}$ & - & - & 11 & 18 & 50 & 82 \\
\hline $\begin{array}{l}\text { 19. Montessori education takes individual } \\
\text { differences into consideration. }\end{array}$ & 3 & 4,9 & 9 & 14,8 & 49 & 80,3 \\
\hline $\begin{array}{l}\text { 20. Children meet some historical terms } \\
\text { such as calendar, time line. }\end{array}$ & 2 & 3,3 & 8 & 13,1 & 51 & 83,6 \\
\hline $\begin{array}{l}\text { 21. Montessori teachers motivate children } \\
\text { by stars, stickers, smiling face and etc. }\end{array}$ & 44 & 72,2 & 11 & 18 & 6 & 9,8 \\
\hline $\begin{array}{l}\text { 22. Children in Montessori classrooms } \\
\text { work together in small groups or by } \\
\text { themselves. }\end{array}$ & 1 & 1,6 & 11 & 18 & 49 & 80,4 \\
\hline $\begin{array}{l}\text { 23. Good manners of children are } \\
\text { strengthened by small prizes or rewards. }\end{array}$ & 52 & 85,2 & 7 & 11,5 & 2 & 3,3 \\
\hline
\end{tabular}




\begin{tabular}{|c|c|c|c|c|c|c|}
\hline $\begin{array}{l}\text { 24. Development of senses is important for } \\
\text { Montessori education. }\end{array}$ & - & - & 7 & 11,5 & 54 & 88,5 \\
\hline $\begin{array}{l}\text { 25. } 3,4,5 \text { and } 6 \text { year-old children are } \\
\text { together in the same classroom (mix age } \\
\text { classrooms) at Montessori education. }\end{array}$ & 4 & 6,7 & 9 & 14,8 & 48 & 78,7 \\
\hline $\begin{array}{l}\text { 26. Children in Montessori education wait } \\
\text { for the teacher's feedback to know how they } \\
\text { are doing on their work during working }\end{array}$ & 19 & 31,2 & 34 & 55,7 & 8 & 13,1 \\
\hline $\begin{array}{l}\text { 27. Montessori teachers expect from } \\
\text { children to do their own work without help } \\
\text { from classmates. }\end{array}$ & 24 & 39,3 & 18 & 29,5 & 19 & 31,2 \\
\hline $\begin{array}{l}\text { 28. Montessori classrooms have natural and } \\
\text { real materials (such as; wooden and metal } \\
\text { materials, glass, grater) }\end{array}$ & 1 & 1,6 & 3 & 4,9 & 57 & 93,5 \\
\hline $\begin{array}{l}\text { 29. Montessori education supports practical } \\
\text { life skills of children. }\end{array}$ & - & - & - & - & 61 & 100 \\
\hline $\begin{array}{l}\text { 30. Montessori education meets children } \\
\text { with some geographical terms such as land- } \\
\text { water-weather, continents, and oceans. }\end{array}$ & 1 & 1,6 & 9 & 14,8 & 51 & 83,6 \\
\hline
\end{tabular}

According to Table 3, 96.8\% of parents living in Ankara gave answer "disagree" to the question of "Montessori education is only for special children", 96.7\% gave answer "disagree" to the question of "Montessori education creates academic pressure on children", $57.4 \%$ gave answer "disagree" to the question of "there are several sets of material in Montessori classes".

According to Table 3,100\% of parents living in Ankara answered "strongly agree" to the question of "Montessori education supports children's daily life skills", 83.6\% answered "strongly agree" to the question of "Montessori education supports creative thinking", $91.8 \%$ of parents answered "strongly agree" to the question of "Montessori education supports children's independence".

Table 4 Parents Awareness of Montessori Education (Sample of Seattle)

\begin{tabular}{|l|c|c|c|c|c|c|}
\hline & \multicolumn{2}{|c|}{ DISAGREE } & \multicolumn{2}{c|}{$\begin{array}{c}\text { SOMEWHAT } \\
\text { AGREE }\end{array}$} & \multicolumn{2}{c|}{$\begin{array}{c}\text { STRONGLY } \\
\text { AGREE }\end{array}$} \\
\hline $\begin{array}{l}\text { 1. Montessori education improves } \\
\text { concentration of children. }\end{array}$ & - & - & 5 & 23,8 & $\mathbf{1 6}$ & $\mathbf{7 6 , 2}$ \\
\hline $\begin{array}{l}\text { 2. Montessori classrooms have multiple sets of } \\
\text { classroom material for each activity so that } \\
\text { children do not have to wait for a turn. }\end{array}$ & $\mathbf{1 5}$ & $\mathbf{7 1 , 4}$ & 3 & 14,3 & 3 & 14,3 \\
\hline \begin{tabular}{l} 
3. $\begin{array}{l}\text { Montessori education supports children's } \\
\text { development of self-discipline. }\end{array}$ \\
\hline
\end{tabular} & - & - & 3 & 14,3 & $\mathbf{1 8}$ & $\mathbf{8 5 , 7}$ \\
\hline
\end{tabular}




\begin{tabular}{|c|c|c|c|c|c|c|}
\hline $\begin{array}{l}\text { 4. Montessori education } \\
\text { independency of children. }\end{array}$ & 1 & 4,8 & - & - & 20 & 95,2 \\
\hline $\begin{array}{l}\text { 5. Montessori education is only for children } \\
\text { who need special education. }\end{array}$ & 21 & 100 & - & - & - & - \\
\hline $\begin{array}{l}\text { 6. Montessori education focuses on academic } \\
\text { success. }\end{array}$ & 7 & 33,3 & 11 & 52,4 & 3 & 14,3 \\
\hline $\begin{array}{l}\text { 7. Montessori education is only suitable for } \\
\text { gifted children. }\end{array}$ & 21 & 100 & - & - & - & - \\
\hline $\begin{array}{l}\text { 8. Children in Montessori classrooms, work at } \\
\text { their own pace. }\end{array}$ & - & - & - & - & 21 & 100 \\
\hline $\begin{array}{l}\text { 9. Montessori education puts pressure on } \\
\text { children about academic success. }\end{array}$ & 20 & 95,2 & 1 & 4,8 & - & - \\
\hline $\begin{array}{l}\text { 10. Montessori education supports creative } \\
\text { thinking. }\end{array}$ & 1 & 4,8 & 4 & 19 & 16 & 76,2 \\
\hline $\begin{array}{l}\text { 11. Montessori education supports children } \\
\text { develop their reading and writing skills. }\end{array}$ & - & - & 4 & 19 & 17 & 81 \\
\hline $\begin{array}{l}\text { 12. Children choose a work through the } \\
\text { will of Montessori teacher. }\end{array}$ & 13 & 61,9 & 7 & 33,3 & 1 & 4,8 \\
\hline $\begin{array}{l}\text { 13. Montessori education supports } \\
\text { children's ability of math. }\end{array}$ & 1 & 4,8 & 2 & 9,5 & 18 & 85,7 \\
\hline $\begin{array}{l}\text { 14. Play is the work of the child according } \\
\text { to Montessori education. }\end{array}$ & 4 & 19 & 8 & 38,1 & 9 & 42,9 \\
\hline $\begin{array}{l}\text { 15. Children meet some biological terms } \\
\text { such as sea animals, farm animals and the } \\
\text { life cycle of animals. }\end{array}$ & - & - & 2 & 9,5 & 19 & 90,5 \\
\hline $\begin{array}{l}\text { 16. Montessori education supports social } \\
\text { skills of children. }\end{array}$ & - & - & 10 & 47,6 & 11 & 52,5 \\
\hline $\begin{array}{l}\text { 17. Children in Montessori classrooms } \\
\text { decide on what they want to work/learn by } \\
\text { themselves. }\end{array}$ & 1 & 4,8 & 8 & 38,1 & 12 & 57,1 \\
\hline $\begin{array}{l}\text { 18. Montessori classrooms have a prepared } \\
\text { environment with materials specially } \\
\text { designed for Montessori education. }\end{array}$ & - & - & - & - & 21 & 100 \\
\hline $\begin{array}{l}\text { 19. Montessori education takes individual } \\
\text { differences into consideration. }\end{array}$ & - & - & 1 & 4,8 & 20 & 95,2 \\
\hline
\end{tabular}




\begin{tabular}{|c|c|c|c|c|c|c|}
\hline $\begin{array}{l}\text { 20. Children meet some historical terms } \\
\text { such as calendar, time line. }\end{array}$ & - & - & 3 & 14,3 & 18 & 85,7 \\
\hline $\begin{array}{l}\text { 21. Montessori teachers motivate children } \\
\text { by stars, stickers, smiling face and etc. }\end{array}$ & 18 & 85,7 & 2 & 9,5 & 1 & 4,8 \\
\hline $\begin{array}{l}\text { 22. Children in Montessori classrooms } \\
\text { work together in small groups or by } \\
\text { themselves. }\end{array}$ & - & - & 5 & 23,8 & 16 & 76,2 \\
\hline $\begin{array}{l}\text { 23. Good manners of children are } \\
\text { strengthened by small prizes or rewards. }\end{array}$ & 20 & 95,2 & - & - & 1 & 4,8 \\
\hline $\begin{array}{l}\text { 24. Development of senses is important for } \\
\text { Montessori education. }\end{array}$ & - & - & 2 & 9,5 & 19 & 90,5 \\
\hline $\begin{array}{l}\text { 25. } 3,4,5 \text { and } 6 \text { year-old children are } \\
\text { together in the same classroom (mix age } \\
\text { classrooms) at Montessori education. }\end{array}$ & - & - & 1 & 4,8 & 20 & 95,2 \\
\hline $\begin{array}{l}\text { 26. Children in Montessori education wait } \\
\text { for the teacher's feedback to know how they } \\
\text { are doing on their work during working }\end{array}$ & 14 & 66,7 & 6 & 28,5 & 1 & 4,8 \\
\hline $\begin{array}{l}\text { 27. Montessori teachers expect from } \\
\text { children to do their own work without help } \\
\text { from classmates. }\end{array}$ & 6 & 28,6 & 12 & 57,1 & 3 & 14,3 \\
\hline $\begin{array}{l}\text { 28. Montessori classrooms have natural and } \\
\text { real materials (such as; wooden and metal } \\
\text { materials, glass, grater) }\end{array}$ & - & - & - & - & 21 & 100 \\
\hline $\begin{array}{l}\text { 29. Montessori education supports practical } \\
\text { life skills of children. }\end{array}$ & - & - & - & - & 21 & 100 \\
\hline $\begin{array}{l}\text { 30. Montessori education meets children } \\
\text { with some geographical terms such as land- } \\
\text { water-weather, continents, and oceans. }\end{array}$ & - & - & 1 & 4,8 & 20 & 95,2 \\
\hline
\end{tabular}

According to Table 4, $100 \%$ of parents living in Seattle gave answer "disagree" to the question of "Montessori education is only for special children", 95.2\% "disagree" to the question of "Montessori education creates academic pressure on children", 71.4\% "disagree" to the question of "there are several sets of materials in Montessori classes".

According to Table 4, 100\% of parents living in Seattle gave answer "strongly agree" to the question of "Children in Montessori classrooms, work at their own pace", $100 \%$ "strongly agree" to the question of "Montessori education supports children's daily life skills" , 95.2\% "strongly agree" to the question of "Montessori education support children's independence"

Montessori education supports many developmental areas of the child. Montessori education contributes in many ways such as love of learning, self-discipline, self-motivation, concentration, self-esteem, sense of order, to the development of the child (Yiğit, 2008). 
In a study conducted by Koçyiğit and Kayılı (2008), attention spans of children aged 5-6 years who got Montessori education and who didn't get was examined and it was found that Montessori materials contributed positively to the attention-gathering skills of children aged five-six (Koçyiğit \& Kayıl1, 2008).

In a study by Eratay, the effectiveness of the Montessori Method was investigated in children with disabled and non-disabled early childhood children. The result was that Montessori education was an effective method for children with disabilities as well as children with normal development (Eratay, 2011).

In a study by Soydan, the strategies for exciting curiosity in the children that Montessori children used were examined. The result is that prepared environment, free choice principle and concentration are effective in exciting curiosity in the children (Soydan, 2013).

Aral et al have examined the effect of Montessori education on child development and found that Montessori education has provided important contributions to many development areas of children such as social emotional development, language development (Aral et al., 2015).

When we look at answers given by parents, it is seen that the answers given by parents living in Ankara and parents living in Seattle are close to each other. Although there are differences in only three questions, this difference does not make a significant difference. In answer to the question "Montessori education is focused on academic success", $75.4 \%$ of the parents living in Ankara answered that they disagree, and 52.4\% of the parents living in Seattle replied that they somewhat agree. In response to the question "Montessori education supports the social skills of children", $88.5 \%$ of the parents in Ankara say they strongly agree, $52.5 \%$ of the parents living in Seattle say they strongly agree. In answer to the question "In Montessori education, the children expect feedback from their teachers", 55.7\% of parents who live in Ankara somewhat agree, and $66.7 \%$ of parents who live in Seattle disagree.

\section{Conclusion and Recommendations}

When we look at answers given by parents, it is seen that the answers given by parents living in Ankara and parents living in Seattle are close to each other. The answers to some questions differ. However, this difference does not make significant difference. The different answers given are as follows:

The majority of parents who live in Ankara and who have been involved in the research have heard Montessori education for the first time from the internet or books / magazines, the majority of parents who live in Seattle and who have been involved in the research have heard Montessori education for the first time from their friends.

Parents were asked with the open-ended question in the form "What do you think the Montessori education will bring to your children?". Parents living in Ankara answered the question self-confidence, self-sufficient, independence, support social development. Parents living in Seattle answered the question self-esteem, independence, natural love of learning, explorative learning. 
"Have you ever taken Montessori education" and "Where did you take from the education" were asked to the parents. It is clear that parents living in Seattle have been taken the education from institutions; parents living in Ankara have been taken the education from the preschool that their children are attending. The number of Montessori educators and the institutions offering Montessori education does not meet the needs in Turkey. Parents in Turkey take Montessori education from preschools that their children attend.

In answer to the question "Montessori education is focused on academic success", $75.4 \%$ of the parents living in Ankara answered that they disagree, and 52.4\% of the parents living in Seattle replied that they somewhat agree. Montessori education includes academic knowledge, but offers this knowledge to the child in accordance with the child's interests and needs and without force. The child never feels pressure on themselves for gaining academic knowledge. Parents in Ankara may have replied that I disagree with this question because they see Montessori education as a liberal education.

In response to the question "Montessori education supports the social skills of children", $88.5 \%$ of the parents in Ankara say they strongly agree, $52.5 \%$ of the parents living in Seattle say they strongly agree. Turkish parents expect that their children will be more social when their children start school. Whether the school is Montessori school or not is not make any difference for them. Therefore, parents who live in Ankara may have responded "I agree".

In answer to the question "In Montessori education, the children expect feedback from their teachers", $55.7 \%$ of parents who live in Ankara somewhat agree, and $66.7 \%$ of parents who live in Seattle disagree. Such a result may be due to differences in the way the Turks and Americans raise children. While American children are independent, Turkish children grow up dependent on their parents. Turkish families don't offer freedom of choice at all. Turkish parents focus on external discipline instead of self-discipline. Therefore many children expect permits, prohibitions, and approvals from their families. When these children start school, they expect similar behaviors from their teachers.

As a result of the study, parents who live in Ankara and send their children to Montessori preschool have knowledge about Montessori system. The awareness of Turkish parents about Montessori education can be considered as reform in education because Montessori approach is an alternative approach to traditional education. The parents who are in pursuit of alternative education will soon be able to influence the Turkish educational system. Montessori approach in Turkey is only for pre-school level now. In the near future, parents are more likely to seek for their children a primary school that has alternative educational approach. Montessori primary schools can be opened in our country according to the demands of parents in near future.

In addition, as a result of the research it is seen that parents who send their child to Montessori preschool have quite high income. Montessori preschools are within the scope private schools in Turkey. I believe that Montessori education will become widespread in time and parents will in the search of public Montessori preschool for their children. We may witness the opening of Montessori public preschools in the near future.

In line with the results obtained; 
- Similar research with other groups of participants would help to broaden understanding of the awareness of parents about Montessori education.

- Mothers' awareness can be compared to fathers' awareness about Montessori education.

- Montessori schools can be increased in number in Turkey.

- Turkish Ministry of Education can conduct seminars to teachers by in-service training.

\section{References}

Aral, N., Yıldız Bıçakçı, M., Yurteri Tiryaki, A., Çetin Sultanoğlu, S., \& Şahin, S. (2015, December). Investigation of The Effects of Montessori Education on Children's Development. 1(1).

Beken, S., \& Şen, S. (2009). The effect of The Activities of Montessori Methtod on The Development of Manual Skills of 5-6 Year-Old-Children. Master Thesis. Adnan Menderes University, Institute of Social Sciences. Aydın.

Can Yaşar, M., \& Aral, N. (2010). The Effects of Early Childhood Education on Creative Thinking Skills. Journal of Theoretical Educational Science, 3(3), pp. 201-209.

Durakoğlu, A. (2010, January-February-March). Reading and Writing Education in Montessorian Method. Journal of family and Society, 5(20).

Durualp, E., \& Aral, N. (2010). A Study on The Effects of Play-Based Social Skills Training on Social Skills of Six-year-old Children. Hacettepe University Journal of Education, 39, pp. 160-172.

Eratay, E. (2011). Efficiency of Montessori Method. Pegem Journal of Education, 1(1), pp. 11-19.

Güral, M. (2015, 09 4). A child's Freedom in Montessori Education Approach. International Journal of Social Science, Autumn 2015(37), pp. 447-457.

Hainstock, E. G. (1997). Teaching Montessori In The Home. New York: First Plume.

Koçyiğit, S., \& Kayıll, G. (2008). A comparison of Montessori and NonMontessori preschool children's Social Skills. Selcuk University, Journal of Social Sciences Institute, pp. 511-516.

Lillard, P. P. (1972). Montessori A Modern Approach. New York: Schocken Books.

Ministry of Education. (2006). Pre-school Education Program: For 36-72 Months Old Children. Ankara: Ministry of Education.

Mallory, T. (1989). Montessori and your Child, Parent's handbook. (F. Öztaş, \& C. Gülten, Trans.) Ankara: Hatipoglu.

Montessori, M. (1965). Dr. Montessori's Own Handbook. New York: Schocken Books.

Montessori, M. (1967). The Discovery of The Child. New York: Balantine Books.

Montessori, M. (1995). Absörment Mind. New York: An Owl.

Oktay, A., \& Polat Unutkan, Ö. (2005). Current Issues in Preschool Education. İstanbul: Morpa .

Soydan, S. (2013). Strategies in Montessori Method That Montessori Teachers Use for Arousing Curiosity in Children. Journal of Mehmet Akif Ersoy University, 13(25), pp. 269-290.

Şahintürk, Ö. (2012). The Effect of Montessori Method on Creavitiyof the Preschool Student Education. Master Thesis. Karaelmas University, Institute of Social Sciences. Zonguldak. 
Ucar \& Durualp (2018). Education Reform Journal, 2018, 3(2), 88-101

Yiğit, T. (2008). The effectiveness of Montessori Method and Traditional Teaching Methods to Gain Number Concept to 4-5 Years of Children Attending Preschool. Master Thesis. Selçuk University. Konya. 